\title{
AZ ESETTANULMÁNY TUDOMÁNYTÖRTÉNETI VÁLTOZÁSAI ÉS DILEMMÁI
}

\author{
CSABAI MÁRTA \\ Szegedi Tudományegyetem Pszichológiai Intézet \\ E-mail: marta.csabai@psy.u-szeged.hu
}

\begin{abstract}
A tanulmány azt mutatja be, hogy milyen tényezók járultak hozzá ahhoz, hogy manapság az esettanulmány reneszánszát figyelhetjük meg különböző tudományterületeken. Több oldalról kívánja alátámasztani, hogy a módszernek önálló kutatási relevanciája van, túl a kutatást elókészítô vagy a kiegészítô, illusztratív, pedagógiai funkciókon. Tudománytörténeti és módszertani szempontból mutatja be, hogy az eset soha nem önmagában áll, hanem dinamikusan illusztrál nagyobb rendszereket, tehát nem csupán egy példa a már meglévố tudásra. Az esettanulmánynak fontos szerep jut a szubjektivitással kapcsolatos diskurzusban, továbbá a tudás státuszával foglalkozó akadémiai vitákban is, igy elsôsorban az általánosithatóság, a tudományos megbizhatóság és a kvantitatív-kvalitatív dichotómia dilemmáiban. Elemzésünk rávilágít, hogy az eseteket a tradíció, a hatalmi struktúrák, a technológiák és tipológiák is alakítják. Bemutatjuk, hogy az esettanulmány miként tudja leírni a tudományos-társadalmi változásokat elsôsorban a normától való eltérés iránti érzékenység és a példaszerüség igénye mentén. Az esettanulmány az egyedi, az általános és a normatív között mozog és az ezekkel kapcsolatos elbeszéléseket és azok változásait reprezentálja. Ez az átmeneti jelleg és pozíció magyarázza az eset eredendôen interdiszciplináris és intertextuális természetét.
\end{abstract}

Kulcsszavak: esettanulmány, tudománytörténet, kevert módszertan, hatalmi praxisok, klinikai esettörténet 


\section{BEVEZETÉS}

A humán tudományokban alkalmazott kutatási és oktatási-kommunikációs eljárások között nagy valószínúséggel az esettanulmány rendelkezik a legellentmondásosabb történeti elôzményekkel és tudományos státusszal. Bár az egyik leghagyományosabb és legismertebb eljárás, mégis számos vita és kérdôjel kísérte a történetét. Ennek egyik jellemzője, hogy a folyamatosan jelen lévô kritikák ellenére az utóbbi közel fél évszázadban, az 1970-es évektôl kezdődôen jelentôs fejlôdés zajlott a módszer alkalmazásában és kutatásában és egyre népszerúbb eljárássá válik a szakmai-tudományos színtéren kívül is. Ebben szerepet játszik, hogy egyre szélesedik az alkalmazási területek köre - a hagyományos klinikai, kutatási és oktatási felhasználáson túl az esettanulmány megjelent például a közgazdaságtan, a politika, a menedzsment és az üzleti kommunikáció területén is. Ezt reprezentálja, hogy napjainkban a társadalomtudományok számos területén, így például a politikatudományi folyóiratok publikációinak több mint felében található esettanulmány (George és Bennett, 2005). Azáltal, hogy a szakemberek háttere, szemlélete is egyre változatosabb, maga a módszertan is sokat fejlôdött. A fejlôdést korábban részben a tudományokat uraló erôs pozitivista szemlélet akadályozta. Az elfogult ellenvélemények szerint az esettanulmány azért nem kaphatott igazi tudományos rangot, mert azt tartották róla, hogy képtelen nagyobb átfogásra, így alkalmatlan általános következtetések levonására (Flyvbjerg, 2006). Esetenként még ma is találkozhatunk ezekkel a véleményekkel, melyek azt sugallják, hogy az eset nem önálló módszer, csak elókészítése egyéb vizsgálódásoknak. Szembeállítják a nagyobb, átfogóbb felméréssel, mintha csupán elôvizsgálati technika lenne, holott a legtöbb tudományterületen a klasszikus, kanonikus szövegek gyakran esettanulmányokhoz kapcsolódnak, vagy mint a pszichológia és a pszichoterápia történetében is ismeretes, ezek a meghatározó szövegek maguk is esettanulmányok.

Különösen figyelemre méltó, hogy a 2000-es években kifejezetten az esettanulmány reneszánszát figyelhetjük meg, amit az is fémjelez, hogy egymás után jelennek meg az eset módszerrel kapcsolatos kézikönyvek, monográfiák (Yin, 2003; Stake, 2006; Gerring, 2016; Bartlett és Vavrus, 2017; Csabai, 2017). Hangsúlyosan reprezentálja ezt az áttörést a 2010-ben a SAGE kiadónál megjelent, több mint 1100 oldal terjedelmú, kétkötetes Encyclopedia of Case Study Research (Mills, Durepos és Wiebe, 2010). A nemzetközi szakirodalomban egyre több tanulmány teszi le a voksot amellett, hogy ennek a módszernek önálló kutatási relevanciája is van, túl az „igazi” kutatást elôkészítô, vagy a kiegészítô, illusztratív, pedagógiai funkciókon. Az esettanulmány módszer lelkes hívei között vannak olyanok, akik egyenesen azt állítják, hogy nincs más múfaj, ami annyira tömören kifejezné a tudás társas dimenzióját, mint ez a metódus (Radley és Chamberlain, 2012; Damousi, Lang és Sutton, 2015). Szerintük az esttanulmánynak dinamikus szerepe van a tudás létrehozásában és továbbadásában akár a diszciplináris, idôi és nemzeti határokat átívelôen is (Forrester, 2015). Hangsúlyozzák, hogy az eset nem egy önmagában álló, izolált jelenség, hanem azzal a képességgel rendelkezik, hogy nagyobb rendszereket és azok dinamikáját is magában foglalja és illusztrálja. Ilyen nagyobb rendszernek tekinthetô például egy tudományos elmélet vagy modell is. Mindezek alapján érdemes röviden áttekinteni, hogy milyen történeti változások vezettek a mai módszertani reneszánszhoz, illetve hogy milyen szemléleti keretekbe rendezôdnek a legfốbb alkalmazások és a hozzájuk kapcsolódó kérdésfelvetések, dilemmák. 


\section{AZ ESETTANULMÁNY STÁTUSZÁNAK VÁLTOZÁSAI}

A legtöbb kutató a 19. század végét és a 20. század elejét jelöli meg az esettanulmány születési idôpontjaként (Harrison, Birks, Franklin és Mills, 2017).) Elsôsorban azokat az antropológiai, etnográfiai, szociológiai terepmunkákat tekintik az eset módszer korai példájának, amelyek egyéni vagy csoportos narratív beszámolók elemzése alapján mutatták be a korabeli társadalmak életvilágát, tapasztalatait. Ilyen híres esettanulmánynak tekintik például Bronislaw Malinowski (1913/2013) kutatását Melanesia ôslakosai körében és a Trobriand-szigeteken, vagy Thomas és Znaniecki (1958/1918-1920) felmérését, melyben lengyel parasztok tapasztalatait vizsgálták Európában és Amerikában.

A nyugati tradíció három klasszikus hivatásában - a jogban, orvostudományban és a teológiában - az eset már az ókortól fontos szerepet töltött be mint a tudás átadásának speciális eszköze. A társadalomtudományokban az elsố hivatalos esettanulmányok a 19. század második felében jelentek meg, fóként az antropológia területén. Utazásokról és más kultúrákban végzett terepgyakorlatokról szóltak ezek a tanulmányok és a részt vevố megfigyelés volt a legjellemzóbb alkalmazott módszer. Az antropológiai megfigyelés módszerét alkalmazták a szociológiában is, elsôként a 20. század elsố felében a Chicagói Szociológiai Iskolában, ahol az esettanulmányok az egyetem környékén végzett megfigyelésekból származtak, és ezekból vontak le következtetéseket a korabeli városi társadalomra vonatkozóan (Whyte, 1943/1993). Ekkor erôsödött meg az orvoslásban és a pszichológiában is az esettanulmány használata, melyet ezeken a szakterületen ekkor inkább esettörténetnek neveztek. Az esettanulmány virágzásában a 19. század második felétôl kezdődôen számos tényezônek szerepe volt: az irodalomban a regény múfaj fejlôdésének, a fejlôdésregény megjelenésének, a detektívregény kialakulásának, melyek szövegtanilag alapozták meg az eset központú elbeszélési formákat (Epstein, 1992; Pethes, 2012). Szintén nagy hatást gyakorolt erre a folyamatra a pszichiátria intézményesülése az orvostudományon belül, mivel itt el kellett különíteni az orvosi és kriminológiai eseteket. Hasonló szerepe volt a társadalmi szabályrendszer és a jog szekularizálódásának, elválásának a vallásos szabályozástól: ennek illusztrálásához is szükség volt a példaértékú, „reprezentatív” esetekre.

A második világháború után a logikai pozitivizmus elooretörésének hatására a társadalomtudományok és az orvostudomány is egyre inkább a statisztikai és kísérletes módszereket helyezte a kutatások elôtérbe, bár több tudományfilozófus kritizálta a természettudományos módszerek társadalomtudományi használatát. Részben ezen kritikák hatására az 1960-as évektôl megjelent az esettanulmányok második generációja, a grounded theory (a „megalapozott elmélet”) módszerét adaptálva, amely a Chicagói Szociológiai Iskola kvalitatív terepvizsgálatát az induktív adatelemzéssel ötvözte (Glaser és Strauss, 1967; Szokolszky, 2004; Kucsera, 2008; Corbin és Strauss, 2015).

Az '80-90-es években fontos hozzájárulást jelentett az eset módszer fejlódéséhez a társadalomtudományok területén, így elsôsorban a szociálpszichológiában és a politikatudományokban megjelenô változás (George, Bennett, 2005). Ez egy olyan komplex szemléletmód bevezetését célozta, melyben egyszerre jelenhettek meg statisztikai és narratív módszerek egy adott vizsgálaton belül, továbbá különbözô tapasztalati eljárások magának az esetnek a kiválasztása során. Ehhez kapcsolódtak kvalitatív összehasonlító elemzések és folyamatkövetéses eljárások. Azáltal, hogy az esettanulmányt 
a politikai intézmények, praxisok és folyamatok komplexitásának illusztrálására tudták alkalmazni, azt is igazolni lehetett, hogy más komplex jelenségek vizsgálatára is alkalmas. Jelentôsen veszített tehát az erejébôl az a korábbi kritika, hogy csak „egydimenziós” jelenségek vizsgálhatók általa (Flyvbjerg, 2006). Ehhez kapcsolódott az 1970-es évektôl az oktatás területén végbemenô folyamat, melyben elsôsorban a képzési tervek, tananyagok értékelésére használták az esettanulmányt, hogy fel tudják mérni a képzések felhasználói tapasztalatait, véleményét és a társas-politikai hatásokat a kimeneti oldal sikerében (Simons, 2009). Ennek részeként kezdték beemelni a konstruktivista megközelítést is a jellemzóen deskriptív esettanulmány-módszertanba, olyan technikákat alkalmazva, mint az induktív exploráció, a felfedezés és a holisztikus elemzés (Stake, 2006). Az alkalmazott területeken zajló további hasonló fejlemények vezettek oda, hogy az eset módszert egyre szélesebb körben kezdték alkalmazni az emberi viselkedés és a társas interakciók legkomplexebb összefüggéseinek megértésében (Harrison, Birks, Franklin, Mills, 2017). Kutatók új generációi képzôdtek ki, akik többféle szemléletben és módszertanban járatosak és ezeket szívesen és sikerrel alkalmazzák kombinált kvalitatív-kvantitatív, „kevert” formában (Devecsery, 2013; Plano Clark, Ivankova, 2015). A tudománytörténeti kutatások is világossá tették az alternatív megközelítések gyökereinek szerves egymáshoz kapcsolódását, továbbá a társadalomtudományok különbözô területei reflektáltak a posztmodern, narratív és egyéb fordulatokra (László, 2005). A természettudományokhoz hasonlóan a társadalomtudományokban is megjelentek a több szempontú és több módszert alkalmazó kutatások, szélesebb teret adva az eset központú szemléletnek és az esettanulmány módszernek.

Mérföldkőnek tekinthetô az esettanulmány történetében az 1980-as években bekövetkezett fordulat, amikor Robert Yin (1984/2003) a kísérleti logikát emelte be a terepmódszertanba, és ezt kombinálta kvalitatív módszerekkel. Másfelôl az 1980-as éveket a „narratív” és az „interpretatív” fordulatok jellemezték a humán és társadalomtudományokban, majd az 1990-es években megjelent a „retorikai” fordulat is (Simons, 1990). Ez utóbbi a diskurzus jelentôségét hangsúlyozza, és azt, hogy a nyelv nem csupán semleges hordozója az általa kifejezett tartalomnak, hanem önálló társas jelentéssel is bír. Mindezek a változások elkezdték megkérdójelezni az empirikus alapok kizárólagosságát, és a konstrukcionista megközelítés felé terelték a figyelmet. Továbbá a természet- és társadalomtudományok szöveges és vizuális reprezentációival szemben a retorikai/diskurzív dimenzióra és a történeti kontextusra irányították a figyelmet. Ettôl kezdôdôen eklekticizmus és pragmatizmus jellemzi az esettanulmányra épülô kutatást. Ezáltal hangsúlyozódott az is, hogy a módszertani ortodoxia helyett azt kell figyelembe venni, hogy az adott kérdés vagy jelenség vizsgálatához mely módszer a legmegfelelóbb, és ez lehet a minôség alapkritériuma. Tehát egy jelenség vizsgálata során ugyanúgy alkalmazhatók kvalitatív és kvantitatív, hermeneutikai vagy statisztikai módszerek. Ily módon, mivel egyik módszert sem részesíti elônyben és nem kötelezódik el a két kultúra egyike mellett sem (sem a természet-, sem a társadalomtudomány paradigmájához), az esettanulmány ideális esetben azt a funkciót is betöltheti, hogy áthidalja a társadalomtudományok módszertani szakadékát, és összekapcsolhatja a kvalitatív és kvantitatív megközelítéseket. Az esettanulmány tehát jó lehetôséget teremthet az interdiszciplinaritásra, több nézőpont és szemléleti keret bevonására egy probléma elemzése, kezelése kapcsán. 


\section{FÖBB KORTÁRS SZEMLÉLETI KERETEK}

Az esettanulmány módszert napjainkban általában három szemléleti keretbe sorolják. Ezek a realista-posztpozitivista, a pragmatikus konstrukcionista és a relativista-konstrukcionista/értelmezô megközelítések (Brown, 2008; Yazan, 2015; Harrison és mtsai, 2017). A realista-posztpozitivista szemléleti keretet leginkább Robert Yin (1984, 2003, 2014) munkái fémjelzik. Yin az esettanulmány legfőbb funkcióját társadalomtudományi vizsgáló módszerként azonosítja, és hangsúlyozza az objektivitás kiemelt szerepét - ezért „realista”. A pozitivizmus új áramlatához, a posztpozitivizmushoz pedig azáltal kapcsolható, hogy fontosnak tartja a kvalitatív kutatás azon jelenkori kívánalmát, hogy megfeleljen az általánosíthatóság és objektivitás kritériumainak. Mindazonáltal fenntartja az alaptételt, hogy egyetlen vizsgálat sem tükrözheti tökéletesen a valóságot: a jelentésadási folyamatok mindenütt árnyalják az eredményeket, és a kutatók már a vizsgálati téma, a dizájn és a választott technikák terén sem tudnak teljesen elfogulatlanok, „objektívek” maradni. Ezért is alkalmaznak az ezen megközelítéshez tartozó kutatók leginkább kevert módszerú, kvalitatív-kvantitatív eljárásokat (Dattilio, Edwards, Fishman, 2010). Gyakran olyan kvalitatív technikákat használnak, ahol az adatok egy késôbbi fázisban kvantifikálhatók és statisztikai módszerekkel tovább elemezhetôk. Ezáltal is próbálják biztosítani, hogy a leíró és értelmezó funkció is megjelenhessen az esettanulmányban, és a szubjektivitás minimálisra legyen csökkenthetô a kutatásban. Továbbá törekszenek arra, hogy olyan kevert módszertant dolgozzanak ki, amely lehetôvé teszi az adott kutatás megismétlését. Ebben a keretben az esettanulmányt az különbözteti meg az egyéb kevert módszerú empirikus vizsgálatoktól, hogy az eset mindig a környezetébe illeszkedik, és azzal együtt képezi a vizsgálat tárgyát.

A másik nagy megközelítés, a pragmatikus konstrukcionista szemléleti keret legfóbb képviselőjének Sharon B. Merriamot (1998, 2009) tartják, aki elsôsorban az esettanulmány oktatási funkciójának tanulmányozásával vált ismertté az 1990-es években (Merriam, 1998). A pragmatikus konstrukcionista megközelítés alap kiindulópontja, hogy a jelentés nem eleve adott, nem „objektív”, hanem társas folyamatok mentén és interszubjektív helyzetekben képzôdik. Az esettanulmány célja ily módon sokkal inkább a jelenségek értelmezése, mint a hipotézistesztelés. Ennek megfelelôen a vizsgálandó esetet is aszerint választják ki, hogy mennyire alkalmas egy adott jelenség ábrázolására, illetve annak feltárására, hogy a jelenséget értelmezó - vagy konstruáló - személy miként éli meg és szervezi a tapasztalatait. Ez az irányzat nem jelöl meg kiemelt módszert az esettanulmányhoz (azt hangsúlyozzák, hogy a témának kell meghatároznia az eljárást), de leggyakrabban mégis kvalitatív technikákat, fóként interjú módszert alkalmaznak, deskriptív, tematikus és tartalomelemzéssel kiegészítve.

A harmadik, relativista-konstrukcionista/értelmezô szemléleti keret meghatározó alakja Robert E. Stake, aki szintén az 1990-es évektôl vált fontos szereplóvé az esettanulmányok kutatásának színterén (Stake, 1995, 2006). Szerinte az esettanulmány elsôdleges funkciója az értelmezés, a jelentés feltárása és a kontextualizált tapasztalatok megértése. Ebben a megközelítésben a kutató szerepe elsôdleges - azaz nem független, „objektív”, hanem szerves része a jelentésadási folyamatnak, melyben ó maga is interaktívan vesz részt. Az esetet nem csupán azért választhatja ki a kutató, mert egy jelenséget reprezentál, hanem mert önmagában is érdekes, a környezetével együtt. 
Ennek megfelelôen leginkább kvalitatív technikákat: interjú módszert vagy részt vevô megfigyelést alkalmaznak az esettanulmány alapjaként ebben a szemléleti keretben.

Természetesen a kutatási gyakorlatban ezek a megközelítések nem különülnek el ilyen élesen. Bár módszertanilag felrajzolható egy kvantitatív-kvalitatív kontinuum, melynek a „kvantitatív” végén inkább a Yin által képviselt szemlélet, míg a "kvalitatív” spektrumban a Stake-féle értelmezô alapállás helyezhetô el, az eset módszerrel történô kutatások gyakran vegyesen alkalmazzák ezeket a szemléleti kereteket. Azért is, mert az esettanulmányt általában komplex jelenségek bemutatására és megértésére használják.

Ahhoz azonban, hogy igazából „reprezentatív” legyen az esettanulmány, megfelelő esetre van szükség. A módszerrel kapcsolatos egyik legnehezebb kérdés, hogy miként választódik ki az eset a tanulmányhoz (Radley és Chamberlain, 2012). Elképzelhetó, hogy a kutató számára maga a konkrét eset és annak belsô jellegzetességei, folyamatai érdekesek. Ekkor az általánosíthatóság nem kérhetô számon. Ha azonban az eset egy tágabb cél érdekében (ami gyakran maga az általánosítás) választódik ki, akkor információgazdagsága, egyedisége, kritikai jellege vagy épp extremitása által is illusztrálhatja a sokaságot - nem csupán azzal, hogy ,jellemzi” azt, tehát a reprezentativitás kritériumát teljesíti. A reprezentativitás azonban nem csupán mint a tudományos kutatás egyik alapkritériuma jelenik meg az eset módszer jellemzójeként, hanem azért is, mert az esetnek hagyományosan van egyfajta modellfunkciója is, azaz példát szolgáltat és precedenst teremthet, illetve szabályozó, normatív szerepet tölthet be különbözô társadalompolitikai gyakorlatok számára.

\section{AZ ESET SZEREPE A NORMALITÁS KONSTRUKCIÓJÁBAN ÉS AZ IDENTITÁSPOLITIKÁBAN}

Az esettanulmánynak fontos szerep jut a szubjektivitással kapcsolatos diskurzusban és a tudás státuszával foglalkozó akadémiai vitákban (Damousi és mtsai, 2015). A 19. században intézményesülő esettanulmány az adatok jegyzókönyvezése, továbbá a tudásdisszemináció alappéldájaként tekinthetô, de fontos szerepet tölt be a modernitás nagy projektjében, az identitásformák létrehozásában, az egyéni viselkedéssel kapcsolatos modellalkotásban, szabályozásban is. Például Freud esettanulmányai a korabeli polgárság számára szolgálhattak iránymutatással, hogy miként éljék meg individualitásukat pszichológiai és szexuális értelemben, és ehhez a születô pszichoterápia - és a pszichoterápiás esettörténet - fogódzókat és példákat is adott. Sokkal populárisabb és köznapibb formában elterjedt alkalmazása volt a pszichológiai eseteknek a Magyar Televízióban hosszú évekig sugárzott músor, a Családi kör, ahol a színészek által bemutatott esetpéldákat magas státuszú szakértố pszichológus kommentálta. Ez a széles nyilvánosság lehetôvé tette, hogy az esettörténet révén a pszichológia a közvélemény egésze számára normatív szerepet tölthessen be a magánélet különbözô színterein. Ilyen és ezekhez hasonló módon jutott a 20. században középponti modellszerep az esettanulmánynak abban, hogy a modern szubjektum létrehozhassa és átkeretezhesse az énjét és identitását, és ebben a hatalompolitikai intézmények is szerepet kaphassanak. Michel Foucault (1963/2000) szerint ez azzal az előzménnyel magyarázható, 
hogy a klinikai tudományok születése már a 18. század végén összekapcsolódik az individuum belépésével a tudás területére. Ez azt jelenti, hogy a személy többé már nem csak a faj egyik egyede, hanem „egyedi példány”. Foucault (1975/1990) szerint az esettanulmány segít megítélni, megmérni, másokhoz hasonlítani az egyént, hogy aztán a hatalom képezhesse, javíthassa, besorolhassa vagy kizárhassa. Ezt jelzi az egyéni leírás, az összehasonlítás, az anamnézis és a „kartoték” (például kórrajz vagy jogi dosszié) intézményes létrehozása. A zárt intézményekben, így tehát az oktatás, a gyógyítás és a büntetés-végrehajtás területén minden egyén „kartoték adattá” és egyúttal a hatalom normalizálási törekvéseinek tárgyává is válik. Foucault szerint különösen az eltérô, deviáns, nehezen besorolható egyénekkel kapcsolatban jelent meg az „esetmunka”. Ez nemcsak a besorolást, kategorizálást jelentette, hanem azt is, hogy miként lehet megérteni - általában egy narratív konstrukció segítségével -, hogy melyek a jellegzetességei az adott esetnek és hogy miként alakult ki. Másfelól az egyén is egyre inkább részt vett, akarva vagy akaratlanul, a saját „esetének” létrehozásában, azaz igazodott a kimondott vagy kimondatlan elvárásokhoz. A moralizáló tanmesék vagy példaként szolgáló memoárok mind modellként szolgáltak az individuális, személyes „esettörténet” (élettörténet), de a professzionális esettanulmány létrehozásához is.

Az eseteket tehát a kulturális és társadalmi tradíció, a hatalmi struktúrák, a vizsgálati-mérési technológiák és tipologizálási törekvések alakítják. Nem véletlen, hogy az esettanulmány mint módszer fellendülése a felvilágosodás és a modernitás, a nagy társadalmi átalakulások idejére tehetô, mivel érzékeny ezekre a változásokra. Részben ezeket mutatja be négy fontos strukturális elem: a biográfia sémája, a fordulópontok dramaturgiája, a normától való eltérés iránti érzékenység és a példaszerúség igénye mentén (Pethes, 2012). Általában szerepe van benne az (élet) történetnek, valamilyen idôstruktúra mentén épül fel, és gyakran a tipikus jellegzetességeket vagy az azoktól való eltérést kívánja bemutatni. Ezért az sem véletlen, hogy a múfaj általában akkor kerül a figyelem középpontjába, amikor nagyobb változás vagy episztemológiai bizonytalanság köszönt be, hiszen az eset az egyedi, az általános és a normatív között mozog, és az ezekkel kapcsolatos elbeszéléseket és azok változásait reprezentálja. Ez az átmeneti jelleg és pozíció magyarázza az eset eredendôen interdiszciplináris és intertextuális természetét is (Pethes, 2012).

Az eset módszer iránt napjainkban megélénküló érdeklődés is magyarázható ilyen változásokkal, így például azzal, hogy a tömegtársadalmak elszemélytelenítô folyamatai között egyre fokozódik az igény az egyéni - és egyedi - tapasztalatok minél több szempontból való átélése, megértése és megosztása iránt. Ez utóbbit jelentôs mértékben elôsegítik és támogatják az internetkultúra és a közösségi oldalak lehetôségei és egyre növekvố népszerúsége is. További ok az egyén jóllétét szolgáló humán szolgáltatások iránti igény növekedése és az orvostudomány fejlődése, amely egyre inkább elérhetố közelségbe hozta a személyre szabott orvoslás lehetôségét. ${ }^{1}$

Az esettanulmány tehát nem csupán egy kutatási módszer, hanem tudást és tudományos emberképet létrehozó és átadó, a tudományos és közgondolkodást egyaránt formáló „reprezentatív anekdota”, mely közönséget alkot, és létre is hoz a közönség

1 Errôl bôvebben lásd „Az egészségpszichológia új kihívásai: A személyre szabott orvoslás ígérete és az esetközpontú szemlélet reneszánsza” címú írásomat a Magyar Pszichológiai Szemle 2017/4. számában. Cs.M. 
számára egyfajta látásmódot azzal kapcsolatban, hogy hogyan nézzen magára és a világra (Cash, 2015). Például az engedelmességgel kapcsolatos, híres Milgram-kísérletrôl szóló tanulmány azt közvetítheti, hogy a legszelídebb emberben is felébreszthetô a destrukció, az engedelmesség mechanizmusa által (Milgram, 1974). Kenneth Burke (1969) szerint a reprezentatív anekdota „jó” és „rossz” típusát különböztethetjük meg. A ,jó” anekdotaként funkcionáló esettanulmány egy nagyobb teoretikus háttérhez kapcsolódik, annak a szervezôdését segíti és azt illusztrálja. Ilyenek a híres esetszerzók: Lurija, Freud, Oliver Sacks vagy Irvin Yalom esettörténetei (ezek elemzését lásd Csabai, 2017). Az esettanulmány ezen típusa azt foglalja össze explicit módon és szükségtelen redukció nélkül, ami a rendszerben benne van implicit módon.

Az eset alanya azonban nem csupán egy személy, egy csoport vagy más társas jelenség lehet, hanem maga az eset módszer is. Tudománytörténeti esetpéldaként érdemes felvillantani, hogy miként ment végbe ez a fejlődés - miként jöttek létre a ,jó" esettanulmányok - a pszichiátria és pszichoterápia történetében, és miként válhattak a vizsgált jelenségeket reprezentáló elbeszéléssé.

\section{A KLINIKAI ESETTANULMÁNY MINT TUDOMÁNYTÖRTÉNETI ESETPÉLDA}

A 18. századig a klinikai esettanulmány nem tudta teljesíteni a „jó” típus követelményeit, mert a funkciója alapvetôen az volt, hogy csupán illusztrációként szolgáljon valamely orvosi tekintély elméletéhez. Majd egyre specifikusabbá vált: a narratív részletek fokozatosan kitértek az idôi és állapotjellemzókre és egyéb adatokra, de még mindig inkább a különleges (furcsa, deviáns), mint a tipikus jellemzóket emelték ki. A 19. századtól válik egyre reprezentatívabbá az esettanulmány azáltal, hogy az egyéni patológiát az általánoshoz kapcsolja és beemel olyan kontextuális jellemzóket is, mint a nem, a társadalmi osztály vagy az anyagi helyzet. A 19. század végére már megjelennek a statisztikai eljárások is (Tougaw, 2006). Ekkor kezdôdik a klinikai esettanulmány megbízhatóságával és pontosságával kapcsolatos szakmai diskurzus is, ami tovább folytatódik a 20. században, amikor az esettanulmány nyelvezete egyre technicizáltabbá válik, a szavak helyét jelentôs mértékben átveszik a számok, egyéb adatok.

A hagyományos esettanulmány (a kórrajz) mindeközben egyszerre alkalmaz retorikai és reprezentációs stratégiákat. Egyszerre jellemzók rá a történeti és irodalmi szövegek létrehozásának ismérvei. A klinikai diagnózis ugyanis magában foglal egy narratív episztemológiát, amely az emberi test tudásparadigmáján alapul, de hasonlítható például a detektívregény felépítésének a sémájához is. Az elbeszélés célja a lehetséges rendellenességek, patológiás jelenségek (a „gyanúsítottak” a krimiben) körének szúkítése, mely folyamat az elsố, benyomásszerú hipotézistôl a konkrét diagnózis felállításáig halad (Stern, 2013). A 19. században külön figyelmet fordítottak arra, hogy a beteg fô panaszát lehetôleg az ô szavaival, pontosan írják le a kórrajzban. Ez azt is jelzi, hogy ekkor valamelyest megváltozott a beteg szerepe is a kapcsolatban: a narrációhoz, az elbeszéléshez - a „megszólaláshoz” - való jog egyfajta autoritáshoz juttatta a személyt (White, 1984). A késóbbiekben - a 20. század második felétôl kezdôdôen - egyre erôsödött a bizonyítékokon alapuló orvoslás igénye, mely sok esetben háttérbe szorította a páciens narratívumok jelentôségét, nem tekintve ezeket elégséges „bizonyítéknak” 
az egyre dominánsabbá váló biológiai és klasszifikációs tendenciák között. Részben az ezekkel kapcsolatos elégedetlenség hatására jelent meg majd a 20. század végén a narratív orvoslás irányzata (Charon, 2006).

A pszichiátria és a pszichológia tehát olyan kettôs identitású területek, ahol tudományos (biomedikális) és narratív (humanisztikus) konvenciók találkoznak a tudományos gondolkodásban és a szakmai diskurzusban egyaránt. A betegekrôl szóló beszámolók egyik, episztemiológiai pólusán a tudományos evidenciákon alapuló beszámolókban, szaktanulmányokban közzétett pozitivista-materialista felvetések állnak, melyek célja a kontextusfüggetlen tudás létrehozása. A másik pólus a narratív megközelítés hermeneutikai kiindulópontja, amely jellemzôen az esettörténetekben tükrözôdik (László, 2005). A tébolydák, azílumok korától egészen a mai, hipertechnicizált biomedicina koráig ezek a történetek álltak a pszichiátriai/ pszichológiai tudás középpontjában.

Külön említést érdemel a pszichoanalitikus/pszichoterápiás esettanulmány, mely új utat mutat a 20. században az élettörténet elbeszélésére, azaz arra, hogy bemutassa, mitôl válik az adott történet specifikusan az adott személy történetévé, de egyúttal publikussá és tudományossá is (Forrester, 1996). Az esetnek azonban van egyfajta tárgyiasító hatása is, mintegy „aktává” válik a strukturált közlés és publikáció által: amint Graham Greene megjegyezte, amikor egy történet „esetté” válik, elveszti emberi jellegét, mert eltúnik belôle a szenvedés és a szégyen (Greene, 2012). A klinikai esettanulmány azonban soha nem tud teljesen megszabadulni a nyelv által közvetített érzelmi anyagától, mert mindig ott van a feszültség a páciens és a szenvedô emberi lény, a szubjektum és a szakértôi reprezentáció között (Epstein, 1992).

\section{PRO ÉS KONTRA ÉRVEK AZ ESET KÖRÜL}

Ezen rövid történeti és tudományelméleti áttekintés után miként foglalhatjuk össze az esettanulmány mellett szóló érveket és a kihívásokat, megoldatlan kérdéseket, melyekkel továbbra is szembe kell nézni a kutatóknak? A témával kapcsolatos viták talán egyik legnagyobb kihívása és félreértéseket, zavart okozó vonatkozása, hogy az eset egyszerre jelenik meg mint módszer (egyedi eljárás, technika) és metodológia (szemlélet, módszertan, kutatási stratégia). Ez részben abból ered, hogy a szakirodalomban sokszor nem különül el, hogy mi a különbség a módszer, a módszertan, a megközelítés, a szemlélet, a stratégia, a kutatási dizájn stb. között (Mills, 2014). Elkülöníti a módszert mint folyamatot és alkalmazott eljárást, technikát, és a módszertant, amely a kutatás tervezésével és véghezvitelével kapcsolatos tervezésben és döntésekben játszik szerepet. Ez az elkülönítés azért is fontos, mert így lehet pontos mind a kutatás-tervezés, mind pedig a kutatás kivitelezése. Továbbá így lehet meghatározni azt is, hogy milyen tágabb szemléleti alapállásra helyezkedik az adott vizsgálat: egy inkább agnosztikus megközelítést követ (mely nem preferál semmilyen filozófiai pozíciót); pozitivista szemléletû (azaz azt feltételezi, hogy egyetlen, a megfigyelôtôl független valóság létezik), vagy inkább relativista, interpretációt hangsúlyozó (azaz azt feltételezi, hogy sokféle realitás létezik és a jelentés létrehozásában a kutatónak aktív szerepe van). Amint azt több szerzố hangsúlyozza, természetesen nem kell éles határt húzni ezek között: az esettanulmányt sokan éppen hídnak tekintik a különbözó paradigmák között, mivel 
alkalmas arra, hogy a legkülönbözóbb nézôpontokat foglalja magába egy vizsgálat során, ezáltal alkalmazkodva a vizsgálandó jelenség komplexitásához (Fishman, Messer, Edwards, Dattilio, 2017). Itt is érdemes hangsúlyozni, hogy ez a módszertani sokféleség nem feltétlenül csak a kvantitatív és kvalitatív dimenziók integrációjával hozható létre: önmagában az egyik dimenzióban is értelmezhetô, hiszen például a kvalitatív módszertan is sokféle szemléletet tükrözhet és célkitúzést tartalmazhat, ami egyaránt lehet feltáró, magyarázó, értelmezô, vagy leíró.

Több szerzó kissé sommásan úgy látja, hogy az esettanulmány erósségei ott találhatók, ahol a statisztikai és formális modelleken alapuló eljárások gyengéi (George és Bennett, 2005). Konkrétabban fogalmazva, ezek az elônyök négy föbb területen jelentkeznek: a konceptuális validitás, az új hipotézisek létrehozása, az egyéni esetek folyamatainak belsố kauzális összefüggései és az oksági komplexitás feltárása terén.

A konceptuális validitás kapcsán kiemelendô, hogy az esettanulmány módszer általában lehetôséget biztosít a kutató számára, hogy meghatározza és mérni tudja azokat az indikátorokat, melyek a legjobban reprezentálják a tesztelni kívánt elméleti koncepciót. A pszichológusok és társadalomtudósok által tanulmányozott jelenségek legtöbbje komplex természetú, és ebből adódóan nem könnyú mérni: sokszor egy jelenség vagy viselkedés másképp manifesztálódik egyik környezetben, mint a másikban (például mást jelent a szolidaritás Észak-Európában, mint Kelet-Ázsiában, vagy más szakmai és társadalmi megítélés alá esik az otthonszülés Hollandiában, mint Magyarországon). Míg a statisztikai eljárásokkal készült elemzések nem tudják elkülöníteni a finom distinkciókat a szükségszerûen nagy elemszám miatt, az esettanulmány ezt ki tudja küszöbölni. Nem ritka, hogy az eset módszert nemcsak a statisztikai eljárást megelőzôn alkalmazzák, a változók meghatározása céljából, hanem utána is, amikor az átlagtól eltérô esetekre tudnak fókuszálni és finomítani a koncepción. Ennek során mutatkozhat meg az eset módszer másik elônye: az új hipotézisek megfogalmazásának a lehetôsége. Gyakran elôfordul ugyanis, hogy az utólagos vizsgálatok során merülnek fel új lehetôségek, melyekre már a statisztikai feldolgozás is rámutatott. A statisztikai módszer azonban önmagában nem elég a hipotézisek megalkotásához, hiszen az ilyen úton létrehozott eredmények szükségszerüen azokat a változókat tartalmazzák, melyeket a kutató oda tartozóként kódolt. Hasonlóképpen az esettanulmány nyújt lehetôséget arra is, hogy nagyszámú változó egymáshoz való viszonyát és kauzális öszszefüggéseit vizsgálni lehessen, akár egyetlen eseten belül is. Szintén az eset módszer adhat lehetôséget a történeti hatások feltárására. Ha például rendelkezésünkre áll az az adat, hogy az otthonukból megszökô kiskorúak döntô részénél szülôi bántalmazás is áll a szökés hátterében, abból még nem következik, hogy egy (vagy több) aktuálisan vizsgált esetnél is biztosan ez az elôzmény. A statisztikai eljárásokkal is kimutatható számos interakciós hatás, de csak azon az áron, hogy nagy mintán végzik a számításokat, és a nemlineáris interakciók modelljei gyakran bonyolulttá és nehezen értelmezhetôvé válnak. Ezeknek az átlátásában és újraértelmezésében is segíthet az esettanulmány, a napjainkban éppen reneszánszát élô, még nagyon sok kiaknázatlan lehetôséget rejtô módszer. 


\section{IRODALOM}

Bartlett, L., \& Vavrus, F. (2017). Rethinking case study research: a comparative approach. New York: Routledge.

Brown, P. A. (2008). A Review of the Literature on Case Study Research. Canadian Journal for New Scholars in Education, 1(1), 1-13.

Charon, R. (2006). Narrative Medicine: Honoring the Stories of Illness. Oxford: Oxford University Press.

Cash, J. (2015). The case study as representative anecdote. In Joy Damousi, Bridget Lang, Katie Sutton (Eds), Case studies and the dissemination of knowledge (pp. 31-49). New York and London: Routledge.

Corbin, J., \& Strauss, A. (2015). A kvalitatív kutatás alapjai. A Grounded Theory elemzési módszer technikája és eljárásai. Budapest: L’Harmattan, Semmelweis Egyetem Mentálhigiéné Intézet.

Csabai M. (2017). Eset - történet. A klinikai mesétôl az esetbankig. Budapest: Oriold és Társai Kiadó.

Damousi, J., Lang B., \& Sutton, K. (Eds), (2015). Case studies and the dissemination of knowledge. New York and London: Routledge.

Dattilio, F. M., Edwards, D. J. A., \& Fishman, D. B. (2010). Case studies within a mixed methods paradigm: Toward a resolution of the alienation between researcher and practitioner in psychotherapy research. Psychotherapy: Theory, Research, Practice, Training, 47(4), 427-441.

Devecsery Á. (2013). A kevert módszerú egészségpszichológiai kutatások. In Csabai Márta, \& Pintér Judit Nóra (szerk.), Pszichológia a gyógyításban Fenomenológiai, múvészetpszichológiai és testkép-központú megközelitések. Budapest: Oriold és Társai Kiadó, 141-167.

Epstein, J. (1992). Historiography, diagnosis, and poetics. Literature and Medicine, 11(1), 23-44.

Fishman, D. B., Messer S. B., Edwards, D. A., \& Dattilio, F. M. (2017). Case Studies Within Psychotherapy Trials Integrating Qualitative and Quantitative Methods. Oxford: Oxford University Press.

Flyvbjerg, B. (2006). 'Five Misunderstandings About Case-Study Research', Qualitative Inquiry, $12,2,219-245$.

Forrester, J. (1996). If p, then what? Thinking in cases. History of the Human Sciences, 9(3), $1-25$.

Forrester, J. (2015). Foreword. In J. Damousi, B. Lang, \& K. Sutton (Eds), Case studies and the dissemination of knowledge (pp. ix-xiii). New York-London: Routledge.

Foucault, M. (1963/2000). Elmebetegség és pszichológia / A klinikai orvoslás születése. Budapest: Corvina.

Foucault, M. (1975/1990). Felügyelet és büntetés. A börtön története. Budapest: Gondolat.

George, A., \& Bennett A.(2005). Case Studies and Theory Development in the Social. Sciences. Cambridge: MIT Press.

George, A. L., \& Bennett, A. (2005). Case studies and theory development in the social sciences (4th ed.). Cambridge, MA: MIT Press.

Gerring, J. (2016). Case Study Research. Principles and Practices. Cambridge: Cambridge University Press.

Glaser, B. G., \& Strauss, A. L. (1967). The Discovery of Grounded theory: Strategies for Qualitative Research. Hawthorne, NY: Aldine.

Greene, G. (2012). A kezdet és a vég. Budapest: Holnap Kiadó.

Harrison, H. Birks M., Franklin, R., \& Mills J. (2017). Case Study Research: Foundations and Methodological Orientations FQS Forum: Qualitative Social Research, 18(1),19-27.

Kucsera Cs. (2008). Megalapozott elmélet: Egy módszertan fejlődéstörténete. Szociológiai Szemle, $18(3), 92-108$. 
László J. (2005). Történetek tudománya. Bevezetés a narratív pszichológiába. Budapest: Új Mandátum Kiadó.

Malinowski, B. (2013). The family among the Australian Aborigines: A sociological study. London: University of London Press.

Merriam, S. B. (1998). Qualitative research and case study applications in education (2nd ed.). San Francisco, CA: Jossey-Bass Publishers.

Merriam, S. B. (2009). Qualitative research: A guide to design and implementation (2nd ed.). San Francisco, CA: Jossey-Bass.

Mills, A., Durepos, G., \& Wiebe, E. (2010). Encyclopedia of Case Study Research. Newbury Park, CA: Sage Publications.

Mills, J. (2014). Methodology and methods. In Jane Mills, Melanie Birks (Eds), Qualitative methodology: A practical guide (pp. 31-47). Thousand Oaks, CA: Sage.

Pethes N. (2012). Az eset esztétikája. A múfaj antropológiai és irodalmi elméleteinek konvergenciájáról. Irodalomtörténet, 93(4), 431-445.

Plano Clark, V. L., \& Ivankova, N. (2015). Mixed Methods Research: A Guide to the Field. Los Angeles: Sage.

Radley, A., \& Chamberlain K. (2012). The study of the case: conceptualising case study research. Journal of Community, Applied Social Psychology, 22(5), 390-399.

Simons, H. (2009). Case study research in practice. Los Angeles, CA: Sage.

Stake, R. E. (1995). The art of case study research. Thousand Oaks, CA: Sage.

Stake, R. E. (2006). Multiple case study analysis. New York, NY: Guilford.

Stern, S. (2013). Detecting Doctrines: The Case Method and the Detective Story. Yale Journal of Law, the Humanities, 23(2), 339-387.

Szokolszky Á. (2004). Kutatómunka a pszichológiában. Metodológia, módszerek, gyakorlat. Budapest: Osiris.

Thomas, W. I., \& Znaniecki, F. (1958 [1918-1920]). The Polish peasant in Europe and America. New York: Dover Publications.

Tougaw, J. D. (2006). Strange Cases. The Medical Case History and the British Novel. New York, London: Routledge.

Whyte, W. F. (1943/1993). Street Corner Society. Chicago: The University of Chicago Press.

Yazan, B. (2015). Three Approaches to Case Study Methods in Education: Yin, Merriam, and Stake The Qualitative Report, 20(2), 134-152.

Yin, R. K. (2003). Applications of case study research (2nd ed.). Thousand Oaks, CA: Sage

Yin, R. K. (1984/2014). Case study research: Design and methods. Los Angeles, CA: Sage. 


\title{
CHANGES AND DILEMMAS OF THE CASE STUDY IN THE HISTORY OF SCIENCES
}

\author{
CSABAI, MÁRTA
}

The paper introduces the factors which may have contributed to the present-day renaissance of the case study method in different scientific disciplines. Our aim is to provide multiple evidence for the independent status of the case study beyond its preparatory, illustrative, or pedagogical functions. By an epistemological-historical-methodological analysis the paper aims to demonstrate that the case is is not a unitary phenomenon and neither an example for existing knowledge but it is able to dynamically illustrate more complex systems. The case study plays an important role in the discourse about subjectivity, and also in academic debates about the status of knowledge concerning mainly the dilemmas of ecological validity, reliability and the quantitativequalitative dichotomy. The study highlights that cases are formed by tradition, power structures, technologies and typologies. Further it shows the ways by which the case study can illustrate social and scientific changes through two structural elements: deviance from the norm, and the need for examples. The case study moves between the individual, the general, and the normative and represents related narratives and their changes. This transitory character and position can explain its interdisciplinary and intertextual nature.

Keywords: case study, history of science, mixed methods, power politics, clinical case history 